\title{
Maxillonasal dysplasia
}

INSERM

\section{Source}

INSERM. (1999). Orphanet: an online rare disease and orphan drug data base.

Maxillonasal dysplasia. ORPHA:1248

Binder syndrome is a rare developmental anomaly, affecting primarily the anterior part of the maxilla and nasal complex. 